\title{
Clinical aspects of trace elements: Zinc in human nutrition - Zinc deficiency and toxicity
}

\author{
Michelle M PluHATOR MSc, AlAN BR THOMSON MD PhD FRCPC FACP FRS FACC, RICHARD N FEDORAK MD FRCPC
}

MM Pluhator, ABR Thomson, RN Fedorak. Clinical aspects of trace elements: Zinc in human nutrition - Zinc deficiency and toxicity. Can J Gastroenterol 1996;10(2):97-103. Available evidence suggests that trace elements, such as zinc, once thought to have no nutritional relevance, are possibly deficient in large sections of the human population. Conditioned deficiencies have been reported to result from malabsorption syndromes, acrodermatitis enteropathica, alcoholism, gastrointestinal disease, thermal injury, chronic diseases (eg, diabetes, sickle cell anemia), and in total parenteral nutrition therapy. Awareness that patients with these problems are at risk has led health professionals to focus increasingly on the importance of zinc therapy in the prevention and treatment of deficiency. More recently zinc toxicity and its role in human nutrition and well-being have come under investigation. Reports have focused on the role of zinc toxicity in causes of copper deficiency, changes in the immune system and alterations in blood lipids. As the numerous challenges presented by the study of zinc in human nutrition are met, more appropriate recommendations for dietary and therapeutic zinc intake are being made.

Key Words: Absorption, Deficiency, Trace element, Toxicity, Zinc

$\mathrm{T}$ his review concludes a five-part series examining zinc in terms of its biochemistry and physiology, metabolism, dietary requirements, nutritional assessment, and states of excess and deficiency.

Trace elements are of great biochemical interest. Scientists have debated whether they are merely dietary contaminants, the bodily requirements of which can be met in all but
Aspects cliniques des éléments traces : le zinc dans la nutrition humaine - déficit en zinc et toxicité

RÉSUMÉ : Selon les preuves recueillies à ce jour, les éléments traces, comme le zinc, autrefois jugés superflus sur le plan de la nutrition, sont probablement déficients chez d'importants groupes de populations. Les déficits conditionnés pourraient résulter du syndrome de malabsorption, de l'acrodermatite entéropathique, de l'alcoolisme, de maladies digestives, de lésions thermiques, de maladies chroniques (comme le diabète, l'anémie à hématies falciformes) et de l'alimentation parentérale. Sachant que ces patients sont exposés à un risque, les professionnels de la santé ont été amenés à s'intéresser à l'importance du traitement à base de zinc dans la prévention et le traitement de ce déficit. Plus récemment, la toxicité liée au zinc et son rôle dans la nutrition et la santé de l'être humain ont fait l'objet de recherche. Certains rapports ont porté sur le rôle de la toxicité liée au zinc dans le déficit en cuivre, sur les changements qui affectent le système immunitaire et sur l'altération des lipides sanguins. À mesure que nous relèverons les défis que représente l'étude du zinc dans la nutrition humaine, nous arriverons à formuler des recommandations appropriées pour l'apport en zinc diététique et thérapeutique.

Division of Gastroenterology, Department of Medicine, University of Alberta, Edmonton, Alberta

Correspondence: Dr RN Fedorak, Division of Gastroenterology, Department of Medicine, University of Alberta, 519 Robert Newton Research Building, Edmonton, Alberta T6G 2C2. Telephone 403-492-6941, fax 403-492-3744, e-mail richard.fedorak@ualberta.ca

Received for publication August 16, 1994. Accepted January 23, 1995 
TABLE 1

\section{Signs and symptoms of zinc deficiency}

Skin lesions

Alopecia

Diarrhea

Hypogeusia

Mental depression

Chronic infections

Impaired wound healing

Abnormal dark adaptation

Anemia

Growth retardation

Hypogonadism

Hypospermia

TABLE 2

Factors predisposing to zinc deficiency

$\begin{array}{ll}\text { Acrodermatitis enteropathica } & \text { Lactation } \\ \text { Alcoholic cirrhosis } & \text { Low socioeconomic status (elderly) } \\ \text { Alcoholism } & \text { Malabsorption syndrome } \\ \text { Anorexia nervosa } & \text { Nephrotic syndrome } \\ \text { Antianabolic drugs } & \text { Pica } \\ \text { Antimetabolic drugs } & \text { Pregnancy } \\ \text { Burns (thermal injury) } & \text { Prematurity } \\ \text { Celiac disease } & \text { Protein-energy malnutrition } \\ \text { Chelating agent therapy } & \text { Protein-losing enteropathies } \\ \text { Chronic blood loss } & \text { Proteinuria } \\ \text { Crohn's disease } & \text { Renal failure } \\ \text { Diabetes mellitus } & \text { Restricted protein diets } \\ \text { Diarrhea } & \text { Short bowel syndrome } \\ \text { Diuretic therapy } & \text { Sickle cell anemia } \\ \text { Excessive sweating } & \text { Starvation } \\ \text { Geophagia } & \text { Steatorrhea } \\ \text { Growth } & \text { Synthetic diets (eg, inborn errors) } \\ \text { Hemolytic anemias } & \text { Total parenteral nutrition } \\ \text { Inflammatory bowel disease } & \text { Uremia } \\ \text { Intestinal resection } & \text { Vegetarianism }\end{array}$

\section{ZINC DEFICIENCY}

Primary zinc deficiency syndrome (ie, due to inadequate dietary intake and/or poor availability) is characterized by dwarfism, hypogonadism, anorexia, mental lethargy and skin lesions (Table 1). This condition was first reported in males from the Middle East (1). Patients with similar symptoms were subsequently encountered in Egypt. In North America and New Zealand, overt and severe nutritional zinc deficiency was first seen in patients receiving either parenteral nutrition or enteral feedings without zinc supplements (2). Later, secondary zinc deficiency (ie, due to states of decreased absorption, excessive excretion and/or excessive use) was also documented in the presence of renal and liver disease, and in association with burns and alcoholism. Two genetic disorders, acrodermatitis enteropathica and sickle cell disease, are also associated with suboptimal zinc status.
The features of severe zinc deficiency occur as part of a recognizable 'syndrome'. Skin lesions resembling acne vulgaris are characteristically the first symptoms to emerge (3-5). Patients often develop alopecia, intractable diarrhea, decreased taste acuity (hypogeusia) and mental depression (3-5). Most patients also acquire chronic infections as a result of immune disorders (3-5). Hypogonadism (in males), abnormal dark adaptation and anemia have been experienced by severely zinc-deficient subjects (4-6). Hepatosplenomegaly has been found in zinc-deficient patients also presenting with severe iron deficiency anemia (6). Because a number of these features are commonly associated with other biological insults that interfere with protein and nucleic acid synthesis, zinc deficiency should only be diagnosed after a thorough clinical investigation and detailed history (3). If untreated, the zinc deficiency syndrome proves to be fatal (4).

\section{ETIOLOGY OF ZINC DEFICIENCY}

Inadequate intake and absorption - Malnutrition: The most common cause of zinc deficiency is malnutrition (6), a disease that is usually associated with other deficiencies including that of other trace elements and protein. Zinc stores in bone and muscle are not readily available under conditions of insufficient oral intake. Therefore, zinc deficiency may easily develop at any time (Table 2). Nutritional zinc deficiency occurs throughout the world, but is more prevalent in developing countries where the chief dietary staples, cereal grains and animal proteins, are lacking from the diet $(6,7)$. In addition, geophagia and pica, practised in both developing and industrialized countries, can render ingested zinc unavailable for absorption (6). Due to the numerous factors that can affect the bioavailability of zinc, borderline zinc deficiencies may be widespread in both North America and western Europe.

Other factors that can predispose one to zinc deficiency include vegetarianism, restricted protein diets, synthetic diets (eg, for the management of inborn metabolic errors) and low socioeconomic status, especially in the elderly $(8,9)$. Plasma zinc concentrations and dietary zinc intake levels have been found to be relatively low in the elderly $(8,10)$, in whom the presence of disease states and/or the use of medications and supplements may more readily precipitate secondary zinc deficiency states (11).

Increased requirements - Pregnancy, lactation and growth: Zinc deficiencies can also be triggered by increased bodily requirements, for example, during pregnancy and lactation, and during the rapid growth phases of infancy, childhood and adolescence (6). Maternal zinc deficiencies may result in congenital malformations, including spina bifida and central nervous system abnormalities. These malformations have, in fact, been prevalent in countries where zinc deficiencies are widely reported (12). In one study, mild zinc deficiencies during pregnancy were associated with increased maternal morbidity, hypogeusia, prolonged gestation, inefficient labour, atonic bleeding and increased risks to the fetus (13). The increase in metabolic requirements for zinc during pregnancy is quite modest, especially early in the gestational period (14). 
In comparison, the increase in metabolic requirements for zinc during lactation is relatively large, especially in the early weeks (14).

In infancy, several factors may contribute to the development of zinc deficiency, including the effects of rapid growth (7). The low zinc concentrations found in infant formulas before regulations requiring routine supplementation with zinc once put American infants at risk (7).

One of the most vulnerable periods with respect to zinc deficiency is during the sexual maturation phase of adolescence. Zinc deficiency has been diagnosed in adolescent males with dwarfism and infantilism; subsequent zinc supplementation results in rapid height gain and growth of sexual organs. Very few studies have addressed zinc deficiency in females.

Congenital zinc absorption defect - Acrodermatitis enteropathica: The most clear-cut human zinc deficiency disorder is acrodermatitis enteropathica, a rare but possibly lethal inherited congenital defect in zinc absorption (3). The disease is not present at birth, but typically develops in the early months of life, soon after the infant is weaned from breast milk. Classic presentation consists of a progressive bullous pustular dermatitis of the extremities and urogenital areas (6). Vomiting, alopecia, diarrhea and failure to thrive are common. Some patients present with neuropsychiatric disturbances including irritability, emotional disorders, tremors and cerebral ataxia (6). Hypogonadism and growth retardation are also prominently evident (6). Zinc therapy offers a complete cure to these patients (7).

Alcoholism: Excessive alcohol consumption exerts an adverse effect on zinc nutriture. Conditioned zinc deficiency has been described for alcoholic individuals both with and without liver cirrhosis (15). It is believed that high alcohol intake induces zinc deficiency via poor dietary intake (16), reduced zinc absorption (17), increased urinary zinc losses $(7,15)$ and decreased affinity of albumin for zinc $(18)$. In a study on ethanol metabolism in postmenopausal women fed a diet marginal in zinc, dietary zinc levels seemed to have a significant effect on alcohol metabolism (19). Compared with levels found during either the control or the zinc repletion periods, more ethanol appeared in the blood and a larger percentage of the peak concentration remained $4 \mathrm{~h}$ after ingestion at the end of the period of marginal zinc intake. These changes may be due to reduced metabolism caused by the actions of alcohol dehydrogenase by the stomach, gut and/or other organs, changes in the rate of gastric emptying and absorption, and changes in renal clearance of alcohol. These data are consistent with those reported by Das et al (20), who conducted studies on rats. The chronically alcoholic person who becomes zinc depleted may be unable to metabolize alcohol adequately, which would render alcohol more toxic to this individual (19).

Gastrointestinal disorders - Diarrhea: The high prevalence of zinc deficiency seen in the developing world has been closely correlated with diarrheal diseases, which result in significantly elevated zinc losses (6). Diarrhea also occurs as a direct result of zinc deficiency in more moderate zinc deficiency states. Changes in intestinal bacteria flora, secondary to deficits in immunocompetence, may play a role in the development of such diarrhea (21). Zinc deficiency has also been reported in patients with steatorrhea $(6,7)$. In an alkaline environment, zinc can be expected to form insoluble complexes with fat and phosphates. Thus, fat malabsorption can result in an increased loss of zinc in the feces (7).

Crohn's disease: A number of studies have suggested that zinc deficiency may be a complication of Crohn's disease. Some clinical features of Crohn's disease are very similar to the clinical manifestations of zinc deficiency. Impaired absorption, increased rate of elimination and poor dietary intake of zinc have all been postulated as possible causes for the zinc deficiency seen in Crohn's disease. Hypogonadism and growth retardation have been frequently observed in Crohn's disease patients who were unable to meet their zinc requirements (7). Crohn's disease is usually accompanied by low plasma zinc values. Fleming and colleagues (22) reported that $46 \%$ of their Crohn's patients had low plasma zinc. Disease activity was found to be correlated to urinary zinc excretion but not to serum zinc, suggesting that disease severity may have a correlative effect on zinc metabolism. Other studies have shown that people with Crohn's disease experience a lower absorption of zinc than controls $(23,24)$.

Celiac disease: Impaired zinc status in patients with celiac disease, as assessed by low plasma zinc concentrations and reduced taste acuity, has been described by Solomons et al (25). Loss of zinc, caused by its binding to fat lost in the stool or by protein-losing enteropathy, may explain, in part, this zinc deficiency state. However, it has been suggested that excessive zinc sequestration in the small intestine due to enhanced mucosal turnover may also be a causative factor (25). The main sites of zinc absorption appear to be the duodenum and jejunum, which are also the sites of the most pronounced mucosal lesion development in celiac disease. Pediatric patients with celiac disease also have low plasma zinc values (26). Chronic diarrhea in this age group may lead to low plasma zinc, and the extent and duration of the diarrhea may relate to the precipitation of a zinc deficiency state (26).

Thermal injury: Burn patients often develop zinc deficiency because of the increased energy needs and exudate losses they experience. Increased urinary zinc excretion is also a welldocumented feature of thermal injury (27). Altered renal handling of zinc observed in thermally injured patients has been shown to result in excessive zinc losses (27). For example, Boosalis et al (27) reported a total urinary zinc loss of $120 \mathrm{mg}$ for the first 30 days after thermal injury. If the losses extend for long periods, or occur in a previously malnourished person, zinc status may be compromised, and this deficiency may affect immune functions and wound healing. The contribution of zinc deficiency to the morbidity of burned patients has not yet been defined (7).

Chronic disease-Sickle cell disease: Sickle cell disease is often accompanied by zinc deficiency. Certain clinical features are common to both, including delayed puberty, male hypogonadism, rough skin, poor appetite and chronic leg ulcers 
TABLE 3

Dosages for treatment of zinc deficiency and maintenance states

\begin{tabular}{|c|c|c|}
\hline State & Form & Dosage \\
\hline \multicolumn{3}{|c|}{ Acute deficiency state } \\
\hline \multirow[t]{2}{*}{ Adult } & Oral & $1.0 \mathrm{mg} / \mathrm{kg} / \mathrm{day}^{*}$ \\
\hline & Intravenous & 0.2 to $0.4 \mathrm{mg} / \mathrm{kg} / \mathrm{day}^{*}$ \\
\hline \multirow[t]{2}{*}{ Children } & Oral & $5.0 \mathrm{mg} / \mathrm{day}^{\dagger}$ \\
\hline & Intravenous & $? 100+\mu \mathrm{g} / \mathrm{kg} / \mathrm{day}$ \\
\hline \multicolumn{3}{|l|}{ Maintenance } \\
\hline \multirow[t]{2}{*}{ Children } & Oral & 2.0 to $9.0 \mathrm{mg} / \mathrm{day}^{\ddagger}$ \\
\hline & Intravenous & $100 \mu \mathrm{g} / \mathrm{kg} / \mathrm{day} \pi$ \\
\hline \multirow[t]{2}{*}{ Stable adult } & Oral & $\begin{array}{l}12.0 \mathrm{mg} / \text { day }(\text { male })^{\ddagger} \\
9.0 \mathrm{mg} / \text { day }(\text { female })^{\ddagger}\end{array}$ \\
\hline & Intravenous & 2.5 to $4.0 \mathrm{mg} / \mathrm{day}^{* *}$ \\
\hline \multicolumn{2}{|c|}{ Adult in acute catabolic state } & $\begin{array}{l}\text { Add } 2.0 \mathrm{mg} / \text { day to maintenance } \\
\text { dose } \mathrm{e}^{\star *}\end{array}$ \\
\hline \multicolumn{2}{|c|}{$\begin{array}{l}\text { Stable adult with intestinal } \\
\text { losses }\end{array}$} & $\begin{array}{l}\text { Add } 12.2 \text { mg for each litre of } \\
\text { small intestinal fluid; add } 17.1 \\
\text { mg for each litre of stool or } \\
\text { ileostomy output** }\end{array}$ \\
\hline \multicolumn{3}{|c|}{ Acrodermatitis enteropathica } \\
\hline & Oral & $35-100 \mathrm{mg} / \mathrm{day}^{\dagger \dagger}$ \\
\hline
\end{tabular}

(7). Because zinc is an important constituent of erythrocytes, the elevated zinc losses that occur with continued hemolysis may lead to a zinc-deficient state. Detailed studies have revealed decreased zinc levels in plasma, erythrocytes, neutrophils and hair (7), and assays of zinc-dependent enzymes have confirmed zinc deficiency states in patients with sickle cell anemia.

Diabetes: Most research on zinc absorption in diabetes has involved the streptozotocin (STZ) rat, and the relevance of such research for diabetic humans still needs to be assessed. Unlike STZ rats, diabetic humans do not show any increases in zinc absorption. Instead, data obtained by Kinlaw and coworkers (28) show that serum zinc uptake is lower in type II diabetes patients. These authors found a correlation between urinary zinc losses and glucose infusions, and they suggest that impaired intestinal absorption and increased urinary losses may produce zinc deficiencies in these patients.

Renal disease: Severe symptomatic zinc deficiencies have not been reported in the case of renal disease, but there is evidence of disturbed zinc metabolism during renal failure. Several studies performed on uremic patients with chronic renal disease have found low zinc concentrations in plasma, leukocytes and hair (29,30). Zinc supplementation for chronic renal patients was shown to improve abnormal taste sensations and to cure impotence (29). The impotence experienced by patients with both chronic renal failure and zinc deficiency may reflect the correlation between zinc deficiency and hypogonadism (6). Prolonged zinc therapy increases the zinc content of leukocytes, hair and plasma (20).

Iatrogenic zinc deficiency: Possible iatrogenic causes of zinc deficiency include use of chelating agents, antimetabolites, antianabolic drugs and diuretics (7). Use of the chelating agent penicillamine in the treatment of Wilson's disease has stimulated severe zinc deficiency (31). Treatment with another aforementioned drug can cause patients to feel ill and become anorectic. The subsequent state of starvation and the catabolism of body mass may lead to increased urinary excretion of zinc. Anticonvulsant drugs, such as sodium valproate, have been implicated in causing zinc deficiency (9). Failure to add zinc to total parenteral nutrition (TPN) is another cause of deficiencies. In such cases, deficiencies can become severe and result in conditions resembling acrodermatitis enteropathica.

\section{TREATMENT OF ZINC DEFICIENCY}

Symptoms of zinc deficiency rapidly resolve after zinc therapy is initiated (6). Table 3 lists dosages for treatment of zinc deficiency and maintenance states. Both oral and intravenous preparations of zinc salts are available. Zinc sulphate heptahydrate $(0.77 \mathrm{mmol}$ of elemental zinc in $220 \mathrm{mg})$ is used commonly, but other salts such as zinc gluconate (205 $\mu \mathrm{mol}$ of zinc in $100 \mathrm{mg}$ ) and zinc acetate $(460 \mu \mathrm{mol}$ of zinc in $100 \mathrm{mg}$ ) can be used.

Zinc salts have a wide therapeutic index and doses should be tailored to match the patient's clinical response (11). For deficiency states, an initial daily dose of $15 \mu \mathrm{mol}$ elemental zinc/ $\mathrm{kg}$ given orally or $5 \mu \mathrm{mol} / \mathrm{kg}$ intravenously has been recommended (11). Therapeutic regimens for the reversal of chronic or acute zinc deficiency symptoms have used 40 to $80 \mathrm{mg}$ intravenous zinc daily or $660 \mathrm{mg}$ oral zinc sulphate daily (32). Moran et al (32) suggested an intravenous dosage of $1 \mathrm{mg} / \mathrm{kg}$ initially to treat an apparent deficiency; the dosage is then lowered to 20 to $40 \mu \mathrm{g} / \mathrm{kg}$ to maintain the stable patient in remission. Daily doses of between 35 and $100 \mathrm{mg}$ of elemental zinc are usually adequate for the management of acrodermatitis enteropathica. However, effective treatment of acrodermatitis enteropathica has been reported with doses only a little in excess (ie, $22 \mathrm{mg}$ elemental zinc) of the American Recommended Dietary Allowance of $15 \mathrm{mg}$ for adults (33).

The Expert Panel for Nutrition Advisory Group, American Medical Association (AMA) Department of Foods and Nutrition, published its guidelines for essential trace element preparations for parenteral use in 1979 (34). Included in the recommendations were the suggested daily doses of intravenous zinc necessary to prevent nutritional depletion. The AMA-recommended intravenous dosage of elemental zinc for pediatric patients is 100 to $300 \mu \mathrm{g} / \mathrm{kg}$. Others have reported requirements of 300 to $500 \mu \mathrm{g} / \mathrm{kg} /$ day for infants and 50 to $100 \mu \mathrm{g} / \mathrm{kg} /$ day for older children (7). Limited data are available for infants weighing less than $1500 \mathrm{~g}$; their requirements may be greater than these recommended dosages because such infants have low body reserves and increased requirements due to their growth. Solomons (35) compiled more refined estimations for TPN zinc requirements from studies of tissue analyses of fetuses and from his experience with patients undergoing parenteral nutrition. His recommendations are $300 \mu \mathrm{g} / \mathrm{kg}$ zinc for premature infants (1.5 to $3.0 \mathrm{~kg}$ ), $100 \mu \mathrm{g} / \mathrm{kg}$ for full term infants (birth to one year), 
$100 \mu \mathrm{g} / \mathrm{kg}$ for preschool children (one to five years), 2.5 to 4.0 $\mathrm{mg}$ for children (five to 12 years) and 2.5 to $4.0 \mathrm{mg}$ for adults (12 years and older). Recommendations for stable adult patients range from 2.5 to $4.0 \mathrm{mg} /$ day.

Under conditions of stress, such as surgery and burns, TPN supplementation requirements may be higher because of increased catabolism, excretion or both (36). Thus, for adults in an acute catabolic state an additional $2.0 \mathrm{mg}$ zinc should be added, increasing the daily intravenous infusion to 4.5 to $6.0 \mathrm{mg}$ (34). For the stable adult patient experiencing significant gastrointestinal losses, an additional $12.2 \mathrm{mg}$ zinc should be added for each litre of small bowel fluid loss or $17.1 \mathrm{mg} / \mathrm{kg}$ of stool or ileostomy output (37). This specific replacement schedule was derived from the mathematical fitting of balance data from a 71-week study of 24 patients with gastrointestinal disease who were receiving TPN. A formula for finding the quantities of zinc to be replaced was developed by the researchers:

zinc replacement $(\mathrm{mg} /$ day $)=2.0 \mathrm{mg}+17.1 \mathrm{a}+12.2 \mathrm{~b}$

where $2.0 \mathrm{mg}$ represents the replacement for urinary losses, a is mass $(\mathrm{kg})$ of stool or ileostomy output and b is mass $(\mathrm{kg})$ of small bowel fluid loss via fistula, stoma or duodenojejunocolostomy (37).

Studies of individuals on TPN have shown that their urinary losses can be elevated or normal $(38,39)$. Urinary excretion of zinc has been noted to exceed $6 \mathrm{mg} /$ day in some instances (39). Therefore, additional allocations beyond the $2.0 \mathrm{mg}$ suggested above may be necessary for individuals experiencing high urinary zinc excretion.

The above AMA-suggested dosages are not absolutes, but serve as guidelines for the initiation of zinc supplementation and baselines for monitoring clinical response. It is, therefore, essential that zinc therapy be individualized giving due consideration to each patient's clinical condition. Renal excretion mechanisms can cope with modest excesses of zinc; however, caution is necessary to ensure against excess dosages, especially if the patient is experiencing renal dysfunction (40).

Monitoring of patient responses to zinc therapy can be accomplished by observing the resolution of clinical symptoms, a process that can begin to occur as rapidly as $24 \mathrm{~h}$ after treatment initiation. Subsequent biochemical analyses of plasma and urinary zinc levels may provide evidence of repletion. It is important to note that biochemical indexes must be interpreted with due consideration for their limitations and potential confounding factors.

\section{ZINC TOXICITY}

Recent attention has focused on the potential effects of zinc toxicity. Most reviews of zinc as an element indicate that it is relatively nontoxic and that humans display considerable tolerance to high intakes (41). For overt symptoms of toxicity to develop, a relatively large amount of zinc must be ingested. However, increasing evidence suggests that zinc supplements, even in modest doses, may cause serious repercussions (41).

\section{TABLE 4}

Causes of zinc toxicity

Food poisoning (galvanized containers)

Inhalation of zinc chloride

High dose zinc supplements

Parenteral zinc poisoning

\section{TABLE 5}

Signs and symptoms of zinc toxicity

\section{Nausea}

Vomiting

Bloody diarrhea

Epigastric pain

Abdominal cramps

Altered blood lipids ( $\uparrow$ LDL, $\downarrow$ HDL)

Copper deficiency

Anemia

Altered immune response ( $\downarrow$ lymphocyte stimulation, $\downarrow$ chemotaxis, $\downarrow$ phagocytosis)

HDL High density lipoprotein; LDL Low density lipoprotein

Causes of zinc toxicity are outlined in Table 4. Most reports of acute toxicity have been related to food poisoning incidents $(41,42)$. Several cases have resulted from the storage of food or drink in galvanized containers; an emetic dose of approximately 1 to $2 \mathrm{~g}$ zinc sulphate, corresponding to 225 to $450 \mathrm{mg}$ zinc, is presumed to have leached out and caused the toxic symptoms of nausea, vomiting, epigastric pain, abdominal cramps and bloody diarrhea (Table 5) (41-43). Other reports of zinc toxicity have been associated with the inhalation of zinc chloride from industrial pollution (43).

Intakes of 100 to $300 \mathrm{mg} /$ day zinc may be prescribed by physicians as treatment for various medical problems, such as sickle cell anemia and celiac disease. However, prolonged therapy with such high doses causes severe copper deficiency $(41,44)$. This level of supplementation is thought to affect copper metabolism by blocking copper absorption from the intestine $(41,43)$. Zinc toxicity may also induce a loss of up to $50 \%$ of iron from the liver, followed by a much later loss of copper (43). Both these losses may result in anemia.

Other reported consequences of zinc intakes of 100 to $300 \mathrm{mg} /$ day include changes in the immune response and blood lipids. In one study subjects took $150 \mathrm{mg}$ zinc twice a day for six weeks, which resulted in a demonstrated reduction in lymphocyte stimulation responses, chemotaxis and phagocytosis of bacteria by polymorphonuclear leukocytes (45). In addition, an increase in low density lipoprotein and a decrease in high density lipoprotein (HDL) were observed, although triglyceride and total cholesterol concentrations did not vary significantly from baseline.

Several studies have provided evidence that zinc supplements of between 15 and $100 \mathrm{mg} /$ day, the amounts most frequently chosen for self-supplementation, may also have adverse results. A number of investigators have shown that copper excretions and requirements are increased as a func- 
tion of increased zinc intakes at these levels (46,47). Zinc supplements may impair copper status unless there is adequate or compensatory copper intake. Alterations in serum lipoproteins have also been seen to accompany lower doses of supplementary zinc. Decreased concentrations of HDL cholesterol as a consequence of zinc dosages of 50 and $75 \mathrm{mg} /$ day for 12 weeks have been described (48). It has also been demonstrated that the cessation of a modest zinc supplement of approximately $30 \mathrm{mg} /$ day was associated with an improvement in HDL levels of healthy elderly subjects (41). Unsupervised supplementation with zinc at these levels should be discouraged.

Although parenteral administration of 2.5 to $4 \mathrm{mg}$ zinc/ day has been recommended, much higher doses have sometimes been infused. Profuse sweating, blurred vision and hypothermia were reported after five daily doses of $10 \mathrm{mg}$ each infused over $1 \mathrm{~h}$ (6). There have been few reported cases of parenteral zinc poisoning. However, in the cases reported in medical journals, most instances were due to errors in prescription (49).

\section{REFERENCES}

1. Okada A, Takagi Y, Nezu R, Lee S. Zinc in clinical surgery. Jpn J Surg 1990;20:635-44.

2. Kay RG, Tasman-Jones C. Acute zinc deficiency in man during intravenous alimentation. Aust NZ J Surg 1975;45:325-30.

3. Golden MHN. Trace elements in human nutrition. Hum Nutr 1982;36:185-202.

4. Prasad AS. Discovery and importance of zinc in human nutrition. Fed Proc 1984:43:2829-34

5. Peereboom JWC. General aspects of trace elements and health. Sci Total Environ 1985;42:1-27.

6. Ronaghy HA. The role of zinc in human nutrition. World Rev Nutr Diet 1987;54:237-54.

7. Prasad AS. Clinical, endocrinological and biochemical effects of zinc deficiency. Clin Endocrinol Metab 1985;14:567-89.

8. Sanstead HH, Henriksen LK, Greger JL, Prasad AS, Good RA. Zinc nutriture in the elderly in relation to taste acuity, immune response, and wound healing. Am J Clin Nutr 1982;36:1046-59.

9. Aggett PJ. Severe zinc deficiency. In: Mills CF, ed. Zinc in Human Biology. London: Springer-Verlag, 1989:259-79.

10. Bunker VW, Hinks LJ, Sansfield MF, Lawson MS, Clayton BE. Metabolic balance studies for zinc and copper in housebound elderly people and the relationship between zinc balance and leukocyte zinc concentration. Am J Clin Nutr 1987;46:353-9.

11. Aggett PJ, Harries JT. Current status of zinc in health and disease states. Arch Dis Child 1979;54:909-17.

12. Sever LE, Emmanuel I. Is there a connection between maternal zinc deficiency and congenital malformations of the central nervous system in man. Teratology 1973;7:117-8.

13. Jameson S. Zinc and pregnancy. In: Nriagu J, ed. Zinc in the Environment. Part II. Health Effects. New York: John Wiley, 1980:183-97

14. Hambidge KM. In: Mills CF, ed. Zinc in Human Biology. London: Springer-Verlag, 1989:281-96.

15. Sullivan JF, Heaney RP. Zinc metabolism in alcoholic liver disease. Am J Clin Nutr 1970;23:170-7.

16. McClain CJ, Su LC. Zinc deficiency in the alcoholic: a review. Alcohol Clin Exp Res 1983;7:5-10.

17. Sullivan JF, Jetton MM, Burch RE. A zinc tolerance test. J Lab Clin Med 1979;93:485-92.

18. Boyett JD, Sullivan JF. Distribution of protein-bound zinc in normal and cirrhotic serum. Metabolism 1970;19:148-57.

19. Milne DB, Canfield WK, Mahalko JR, Sandstead HH. Effect of oral folic acid supplements on zinc, copper and iron absorption and excretion. Am J Clin Nutr 1984;39:535-9.

20. Das I, Burch RE, Hahn HKJ. Effects of zinc deficiency on ethanol metabolism and ethanol and aldehyde dehydrogenase activities. J Lab Clin Med 1984;104:610-7.

\section{CONCLUSIONS}

The extent to which deficiencies and excesses of zinc influence human health and well-being has been a popular subject of debate. No other trace element has been credited with such a variety of biochemical functions. Despite this interest, many difficulties still exist in relating these biochemical functions to specific diagnostic signs of human zinc deficiency and toxicity. Deficiency symptoms are nonspecific, and there is a lack of information about which of the many zinc pools is the most vulnerable, as well as about the mechanism by which this pool exerts its effects. As a result, interpreting and assessing the zinc status of the individual is a challenge.

This review has outlined risk factors for the development of zinc deficiency and suggested guidelines for individualized zinc replacement. As we increasingly meet the many challenges presented by the study of zinc in human nutrition, more appropriate recommendations for the dietary and TPN zinc intake of individuals with diverse zinc needs will be forthcoming.

21. Hambidge KM, Casey CE, Krebs NF. Zinc. In: Mertz W, ed. Trace Elements in Human and Animal Nutrition, 5th edn. Toronto: Academic Press Inc, 1986:1-137.

22. Fleming CR, Huizenga KA, McCall JT, Gildea J, Dennis R. Zinc nutrition in Crohn's disease. Dig Dis Sci 1981;26:865-70.

23. Sturniolo GC, Molokhia MM, Shields R, Turnberg LA. Zinc absorption in Crohn's disease. Gut 1980;21:387-9.

24. Valberg LS, Flanagan PR, Kertesz A, Bondy DC. Zinc absorption in inflammatory bowel disease. Dig Dis Sci 1986;31:724-31.

25. Solomons NW, Rosenberg IH, Sandstead HH. Zinc nutrition in celiac sprue. Am J Clin Nutr 1976;29:371-5.

26. Guerrieri A, Catassi C, Pasquini E, Coppa GV, Benetti E, Giorgi PL. Plasma zinc levels in children with chronic diarrhea. Eur J Pediatr 1986;145:563-4.

27. Boosalis MG, Solem LD, Cerra FB, et al. Increased urinary zinc excretion after thermal injury. J Lab Clin Med 1991;118:538-45.

28. Kinlaw WB, Levine AS, Morley JE, Silvis SE, McClain CJ. Abnormal zinc metabolism in type II diabetes mellitus. Am J Med 1983;75:273-7.

29. Mahajan SK, Prasad AS, Rabbani P, Briggs WA, McDonald FD. Zinc metabolism in uremia. J Lab Clin Med 1979;94:693-8.

30. Mahajan SK, Abbasi AA, Prasad AS, et al. Effect of oral zinc therapy on gonadal function in hemodialysis patients: a double-blind study. Ann Intern Med 1982;97:357-61.

31. Klingberg WG, Prasad AS, Oberleas D. Zinc deficiency following penicillamine therapy. In: Prasad AS, Oberleas D, eds. Trace Elements in Human Health and Disease. New York: Academic Press, 1976:51-65.

32. Moran DM, Russo J Jr, Bell LV. Zinc deficiency dermatitis accompanying parenteral nutrition supplemented with trace elements. Clin Pharm 1982;1:169-76.

33. Nelder KH, Hambige KM. Zinc therapy of acrodermatitis enteropathica. NJ Med 1975;292:879-82.

34. American Medical Association Department of Foods and Nutrition. Guidelines for essential trace element preparations for parenteral use. JAMA 1979;241:2051-4.

35. Solomons NW. Biological availability of zinc in humans. Am J Clin Nutr 1982;35:1048-75.

36. Michie DD, MacFarlane D, Wirth FH. Zinc and total parenteral nutrition. South Med J 1977;70:985-7.

37. Wolman SL, Anderson GH, Marliss EB, Jeejeebhoy KN. Zinc in total parenteral nutrition: requirements and metabolic effects. Gastroenterology 1979;76:458-67.

38. Kay RG, Tasman-Jones C, Pylous J, et al. A syndrome of acute zinc deficiency during total parenteral nutrition in man. Ann Surg 1976;183:331-40.

39. Takagi Y, Okada A, Itakura T, Kawashima Y. Clinical studies on zinc metabolism during total parenteral nutrition as related to zinc deficiency. J Parenter Enteral Nutr 1986;10:195-202. 
40. American Medical Association Department of Foods and Nutrition. Guidelines for essential trace element preparations for parenteral use. JAMA 1979;241:2051-4.

41. Fosmire GJ. Zinc toxicity. Am J Clin Nutr 1990;51:225-7.

42. Faintuch J, Faintuch JJ, Toledo M, Nazario G, Machado MCC, Raia AA. Hypermylasemia associated with zinc overdose during parenteral nutrition. J Parenter Enteral Nutr 1978;2:640-5.

43. Guthrie HA. Micronutrient elements. In: Bagby RS, ed. Introductory Nutrition, 7th edn. Toronto: Times Mirror/Mosby College Publishing, 1989:289-335.

44. Prasad AS, Brewer GJ, Schoomaker EB, Rabbani P. Hypocupremia induced by zinc therapy in adults. JAMA 1978;240:2166-8.

45. Chandra RK. Excessive intake of zinc impairs immune responses. JAMA 1984;252:1443-6.
46. Sandstead HH. Copper bioavailability and requirements. Am J Clin Nutr 1982;35:809-14.

47. Festa MD, Anderson HL, Dowdy RP, Ellersieck MR. Effect of zinc intake on copper excretion and retention in man. Am J Clin Nutr 1985;41:285-92.

48. Black MR, Medeiros DM, Brunett E, Welke R. Zinc supplements and serum lipids in young adult white males. Am J Clin Nutr 1988;47:970-5.

49. Brocks A, Reid H, Glazer G. Acute intravenous zinc poisoning. BMJ 1977;i:1390-1.

50. Walravens PA, Hambidge KM, Koepfer DM. Zinc supplementation in infants with a nutritional pattern of failure to thrive: a double-blind controlled study. Pediatrics 1989;83:532-8.

51. Health and Welfare Canada. Nutrition Recommendations. Ottawa: Health and Welfare Canada, 1990. 


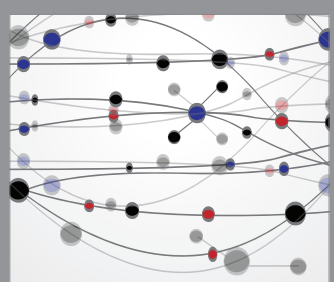

The Scientific World Journal
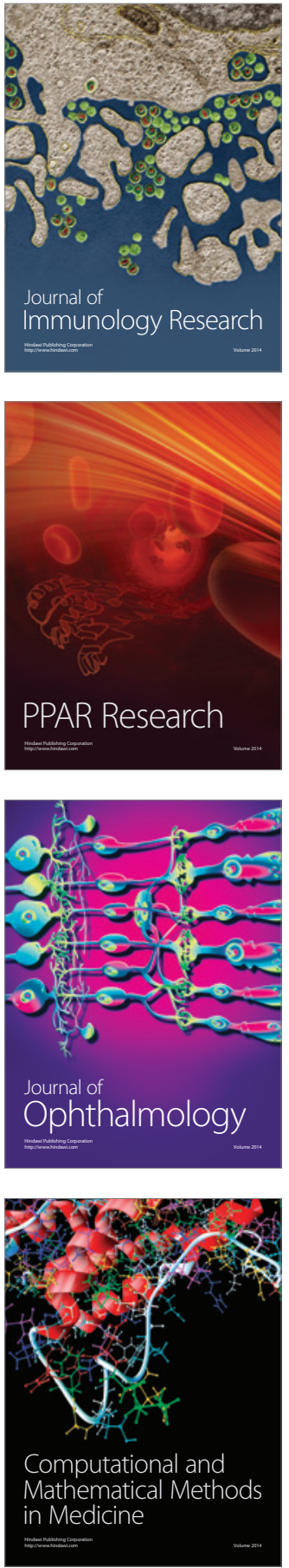

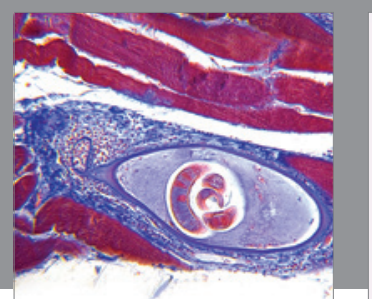

Gastroenterology Research and Practice

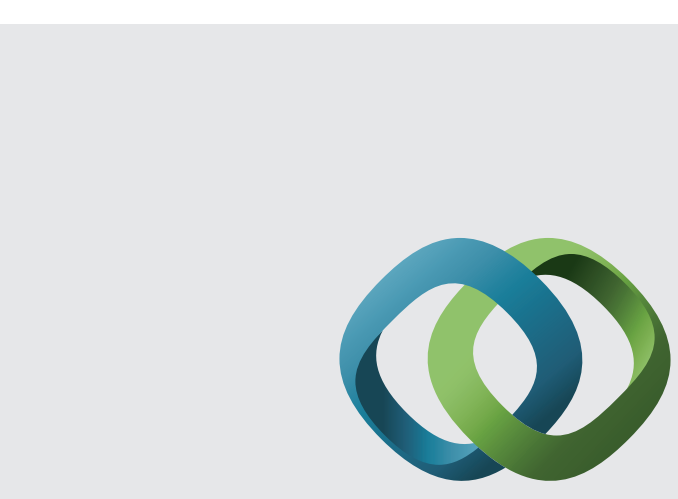

\section{Hindawi}

Submit your manuscripts at

http://www.hindawi.com
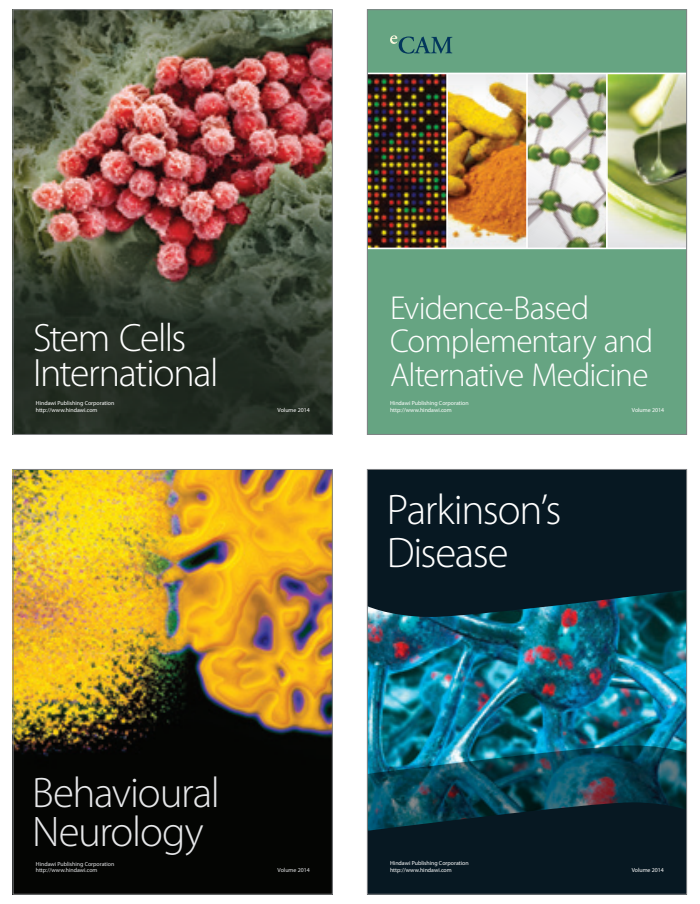
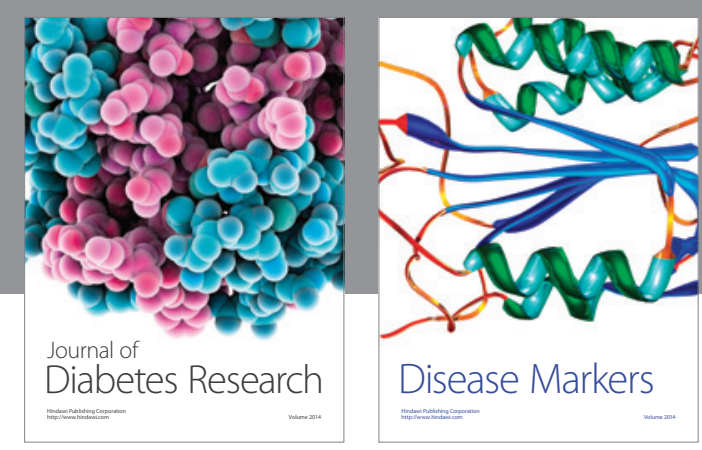

Disease Markers
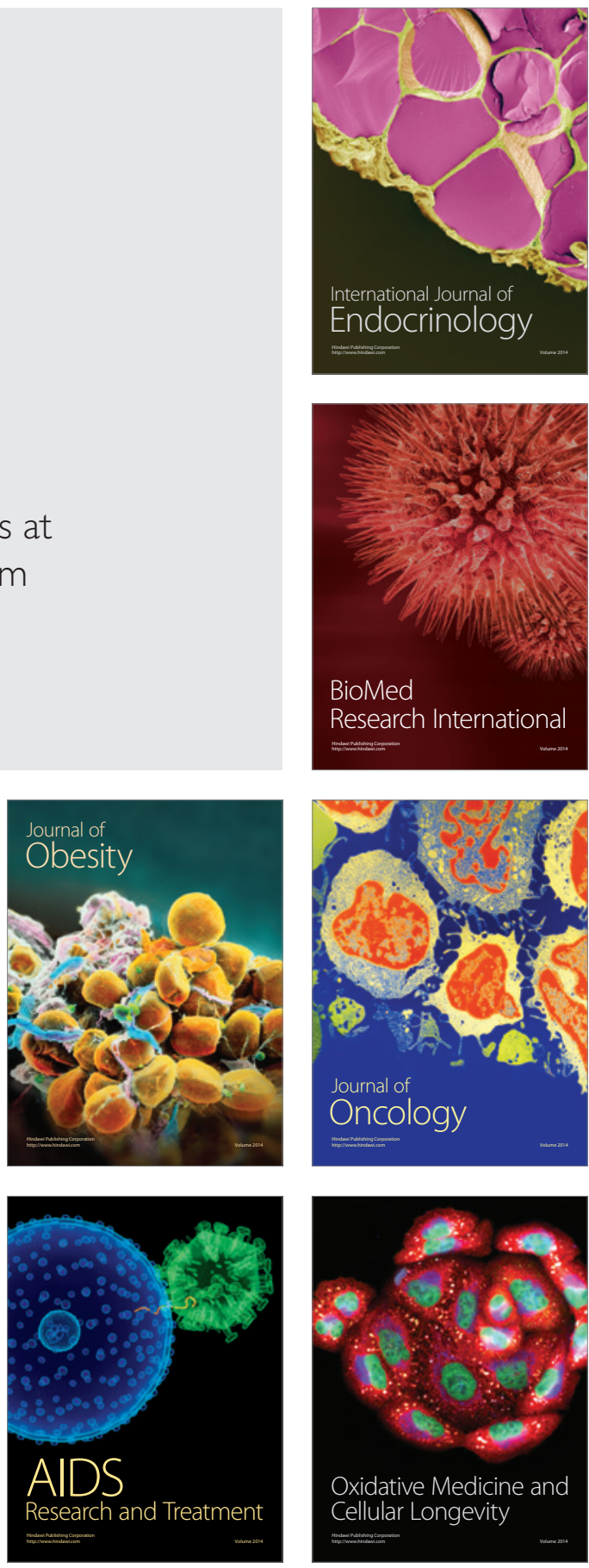